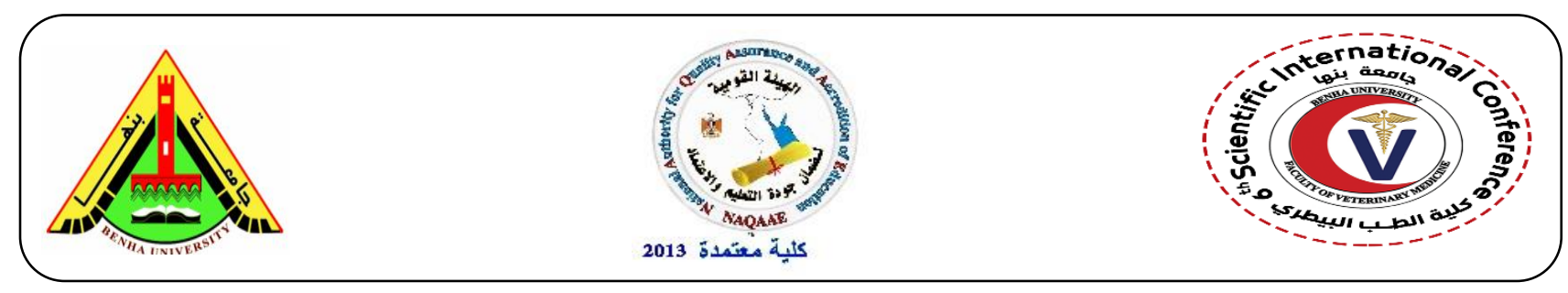

\title{
Disposition Kinetics and Tissue Residues of Cefotaxime in Healthy and Experimentally Staphylococcus Aureus Infected Broiler Chickens
}

\author{
El-Sayed, M. G. A., Aboubakr, ${ }^{*}$ M.\& Rabea, Samar \\ Department of Pharmacology, Faculty of Veterinary Medicine, Benha University, Egypt. \\ Corresponding author*: Mohamed Aboubakr: mohamed.aboubakr@fvtm.bu.edu.eg
}

\section{A B S T R A C T}

The pharmacokinetic parameters of cefotaxime were studied following I.V. and I.M. (single \& repeated) injection in normal and experimentally Staphylococcus aureus infected broiler chickens. Following a single intravenous injection of $25 \mathrm{mg}$ cefotaxime/kg b.wt in normal chickens, cefotaxime could be detected therapeutically for 12 hours post intravenous injection with mean value $2.34 \mu \mathrm{g} / \mathrm{ml}$. The serum concentration - time curve of cefotaxime following intravenous injection showed that the drug obeyed two compartments open model with elimination half- life $\left(\mathrm{t}_{0.5(\beta)}=3.11 \mathrm{~h}\right)$, volume of distribution $\left(\mathrm{V}_{\mathrm{dss}}=496.90 \mathrm{ml} / \mathrm{kg}\right)$ and total body clearance of the drug $\left(\mathrm{CL}_{\mathrm{tot}}=137.63 \mathrm{ml} / \mathrm{hr} / \mathrm{kg}\right)$. Following a single intramuscular injection of $25 \mathrm{mg} / \mathrm{kg}$ body weight cefotaxime in normal chickens, the peak plasma concentration $\left(\mathrm{C}_{\max }\right)$ was $19.54 \mu \mathrm{g} / \mathrm{ml}$ was achieved at a maximum time $\left(\mathrm{T}_{\max }\right)$ of $2.42 \mathrm{~h}$. The intramuscular bioavailability of cefotaxime in normal chickens was $81.92 \%$. Intramuscular injection cefotaxime twice daily for five consecutive days in normal and Staphylococcus aureus infected chickens revealed a lower significant serum cefotaxime concentration after the first, third, fifth, seventh, ninth doses in Staphylococcus aureus infected chickens compared with normal chickens. Cefotaxime showed accumulative behavior in blood of chickens. After repeated intramuscular injection of $25 \mathrm{mg}$ cefotaxime/kg b.wt every $12 \mathrm{~h}$, cefotaxime was assayed in liver, kidney, lung, heart, breast muscle, thigh muscle and skin after 24, 48, 72, 96, 120 and $144 \mathrm{~h}$ post last dose. Drug concentrations in liver, kidney and lung were (23.17 \pm 0.614$)$ $(15.51 \pm 0.31),(16.69 \pm 0.405)(10.94 \pm 0.04)$ and $(14.04 \pm 0.52)(7.92 \pm 0.395) \mu g / g$ in normal and Staphylococcus aureus infected chickens respectively 24 hours after the stoppage of drug medication. Cefotaxime was completely cleared from tissues at 144 and 120 hours after the stoppage of drug dosage in normal and Staphylococcus aureus infected chickens. Results of this study indicated that cefotaxime was useful for treatment of Staphylococcus aureus infections in chickens. Key words: Pharmacokinetics, cefotaxime, tissue residues, broiler chickens.

(http://www.bvmj.bu.edu.eg)

(BVMJ-34(3): 295-309, 2018)

\section{INTRODUCTION:}

The pharmacokinetics of cefotaxime

has been investigated in sheep (Guerrini et 
al., 1983), dogs (Guerrini et al., 1986), cats (McElory et al., 1986), goats (Atef et al., 1990; Dutta et al., 2004; Elsayed et al., 2015b), cattle (Sharma et al., 1995), horses (Orsini et al., 2004), buffaloes (Sharma et al., 2003; Sharma and Srivastava, 2006) and muscovy ducks (Aboubakr, 2016).

Therefore, the present work aimed study the pharmacokinetic parameters of cefotaxime after intravenous and intramuscular injections normal and experimentally Staphylococcus aureus infected chickens. Also, the bioavailability of cefotaxime was calculated after intramuscular injection in normal chickens. Residues for cefotaxime in chickens's tissues were studied in normal and Staphylococcus aureus infected chickens.

\section{MATERIALS AND METHODS}

\subsection{Drug:}

Cefotaxime was used in this study under trade name (Cefotax ${ }^{\circledR}$, sterile vial), each vial contains cefotaxime sodium $1048 \mathrm{mg}$ equivalent to ceftaxime $1000 \mathrm{mg}$. Each $\mathrm{ml}$ of reconstituted solution contains cefotaxime sodium equivalent to $1000 \mathrm{mg}$ cefotaxime, which was manufactured by Egyptian International Pharmaceutical Industries company (E.I.P.I.Co ) $10^{\text {th }}$ of Ramadan City industrial area B1, EGYPT.

\subsection{Experimental birds:}

Forty-six clinically normal Hubbard chickens of four weeks of age weighting about 1500 to $2000 \mathrm{gm}$, each chosen randomly from poultry farm, Qalubia government, EGYPT, were used in investigation. Chickens were feed balanced ration free from antibacterial for two weeks to ensure complete excretion of any drugs from their bodies. Water and feed free from antibacterial additives were provided $a d$ libitum.

\subsection{Experimental design}

Chickens were divided into 3 groups:

Group (1):

It includes six normal chickens were administered intravenously into the wing vein with single dose of $25 \mathrm{mg}$ cefotaxime / $\mathrm{kg}$. b.wt. (Aboubaker, 2016). These chickens were left for 15 days after the intravenous injection to ensure complete elimination of cefotaxime from their bodies and then administered intramuscularly with $25 \mathrm{mg}$ cefotaxime per kilogram body weight, to determine the bioavailability of cefotaxime in normal chickens.

\section{Group (2):}

It includes twenty normal chickens were administered intramuscularly $25 \mathrm{mg}$ cefotaxime per kilogram body-weight twice daily for five consecutive days, to determine pharmacokinetics and at the end of fifth day of administration, three chickens were slaughtered after 24, 48, 72, 96, 120 and $144 \mathrm{~h}$ post last administration to determine tissue residues of cefotaxime.

Group (3):

It includes twenty experimentally Staphylococcus aureus infected chickens were injected intramuscularly $25 \mathrm{mg}$ cefotaxime / $\mathrm{kg}$. b.wt. twice daily for five consecutive days after the appearance of the symptoms, 48 hours after experimental infection with Staphylococcus aureus to determine pharmacokinetics and tissue residue of cefotaxime. Each chicken was intramuscularly challenged with $1 \mathrm{ml}$ of concentration of $2.5 \times 10^{9}$ c.f.u/ml of Staphylococcus aureus suspension (Staphylococcus aureus ATCC 29213 strain of poultry origin was obtained from Poultry Department, Animal Health Research Institute- Dokki, Giza, EGYPT) according to $\mathrm{Gu}$ et al., (2013). After the 
appearance of symptoms of bacteremia as chickens suffering from severe watery diarrhea, lack of appetite, ruffled feathers, drooping wings, skin reddening, swollen joint and lameness, each chickens was injected with $25 \mathrm{mg}$ cefotaxime/ $\mathrm{kg}$ b.wt every $12 \mathrm{~h}$ for five consecutive days. After that tissue samples were taken for assaying of residues till disappearance of the drug from tissue.

\subsection{Collection of samples:}

\subsubsection{Blood samples}

About one milliliter of blood was taken from the right-wing vein, following injection of the drug. Blood samples were collected at 5, 10, 25, 30 minutes, 1, 2, 4, 6, 8, 12 and $24 \mathrm{~h}$ after single intravenous and intramuscular injection of cefotaxime. Blood samples following repeated intramuscular injection of cefotaxime in normal and experimentally infected chickens for 5 consecutive days were collected at 15, 30 minutes, 1, 2, 4, 6, 8, $12 \mathrm{~h}$ and before third, fifth, seventh and ninth doses.

All blood samples were collected in sterilized centrifuged tubes and allowed to clot. Serum was separated by centrifugation for 15 minutes at 3000 r.p.m. Sera were kept frozen until assayed.

\subsubsection{Tissue samples}

At the end of fifth day of repeated I.M. injection of cefotaxime, three chickens were slaughtered from group (2) and group (3). From each slaughtered chicken, samples of brain, heart, lung, liver, kidney, breast muscle, thigh muscle, fat and skin were taken for assaying of residues of cefotaxime at 24,48 , $72,96,120$ and $144 \mathrm{~h}$ after last dosing.

\subsection{Analytical procedure:}

Cefotaxime in both collected blood and tissue samples were assayed using microbiological method of antibiotic according to Arret et al., (1971), using E. coli ATCC 6633 as test organism for cefotaxime. The test organism was obtained from Department of Microbiology, Animal Health Research Institute, Dokki, Giza, EGYPT.

Three plates were used for each sample. One well in each plate was filled with reference concentration $(6.25 \mu \mathrm{g} / \mathrm{ml}$ of cefotaxime in distilled water or normal chickens' serum). The plates were incubated at $37^{\circ} \mathrm{c}$ for $24 \mathrm{~h}$, then the diameter of inhibitory zones was measured. The average diameter of inhibition zone of the samples was corrected by using the diameter of the reference concentration as mentioned previously in the preparation of the standard curve. From the standard curve, the concentration corresponding to the correct values of the zone diameter were obtained.

Assay of tissue samples, two grams of tissue were homogenized by automatic homogenizer with $2 \mathrm{ml}$ of distilled water. Mixtures were centrifuged at 3000 r.p.m. for 10 minutes and the supernatant fluid of each sample was taken and directly assayed microbiologically for cefotaxime concentration.

\subsection{Pharmacokinetic analysis}

The pharmacokinetics parameters were calculated by Winnonlin program, version 4.1 and other parameters according to Ritchel (1973) and Baggot (1978 a\&b).

\subsection{Statistical analysis}

Data were expressed as mean \pm S.E. The obtained data were statistically analyzed using Student $t$-test to express the differences between groups and pharmacokinetic parameters Snedecor and Cokran (1980).

\section{RESULTS:}

Following a single I.V. injection of 25 $\mathrm{mg}$ cefotaxime/kg b.wt. in normal chickens, 
cefotaxime could be detected therapeutically for 12 hours post intravenous injection. The plasma concentration-time curve of cefotaxime following intravenous injection showed that the drug obeyed two compartments open model. The disposition kinetics of cefotaxime following a single intravenous and intramuscular injection were recorded in table (1) and showed in figure (1).

Intramuscular injection of 25 $\mathrm{mg} / \mathrm{kg}$.b.wt every 12 hours for five consecutive days in normal and Staphylococcus aureus infected chickens revealed a lower significant plasma cefotaxime concentration at all-time sampling in Staphylococcus aureus infected chickens than in normal chickens. The pharmacokinetic parameters of cefotaxime after repeated oral administration in normal chickens were compared to those in Staphylococcus aureus infected chickens (Table 2).

Tissue samples from liver, kidney, lung, heart, breast muscle, thigh muscle, skin and fats were taken for assaying of residues of cefotaxime at 24, 48, 72, 96,120 and 144 hours after the last intramuscular dose of 25 $\mathrm{mg} / \mathrm{kg}$.b.wt from normal chickens were compared to those in Staphylococcus aureus infected chicken (Table3).

Table 1: Pharmacokinetic parameters of cefotaxime following a single intravenous and intramuscular injection of $25 \mathrm{mg} / \mathrm{kg}$ b.wt. in normal chickens $(\mathrm{n}=6)$.

\begin{tabular}{|c|c|c|c|}
\hline & nit & Intravenous & Intramuscular \\
\hline$\overline{\mathrm{C}^{0}}$ & $\overline{\mu \mathrm{g} / \mathrm{ml}}$ & $119.83 \pm 2.46$ & - \\
\hline$\overline{\mathrm{A}}$ & $\mu \mathrm{gg} / \mathrm{ml}$ & $85.34 \pm 2.34$ & - \\
\hline$\overline{\mathrm{A}}$ & $\overline{\mathrm{h}^{-1}}$ & $2.97 \pm 0.313$ & - \\
\hline $\mathrm{t}_{0.5(\alpha)}$ & $\overline{\mathrm{h}}$ & $0.246 \pm 0.025$ & - \\
\hline$\overline{\mathrm{K}_{12}}$ & $\overline{\mathrm{h}^{-1}}$ & $1.51 \pm 0.207$ & - \\
\hline$\overline{\mathrm{K}_{21}}$ & $\mathrm{~h}^{-1}$ & $1.02 \pm 0.088$ & - \\
\hline 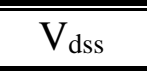 & $\overline{\mathrm{ml} / \mathrm{kg}}$ & $496.90 \pm 15.47$ & - \\
\hline$\overline{\mathrm{B}}$ & $\overline{\mu \mathrm{g} / \mathrm{ml}}$ & $3434.41 \pm 0.640$ & $\overline{-1}$ \\
\hline $\bar{\beta}$ & $\overline{h^{-1}}$ & $0.224 \pm 0.009$ & - \\
\hline $\mathrm{t}_{0.5(\mathrm{el})}$ & $\overline{\mathrm{h}}$ & $3.11 \pm 0.113$ & $3.7 \pm 0.221$ \\
\hline AUC & $\overline{\mathrm{hr} / \mu \mathrm{g} / \mathrm{mL}}$ & $181.92 \pm 3.19$ & $149.02 \pm 3.78$ \\
\hline AUMC & $\mathrm{hr} / \mathrm{h} / \mu \mathrm{g} / \mathrm{ml}$ & $656.37 \pm 18.04$ & $932.52 \pm 57.01$ \\
\hline MRT & $\bar{h}$ & $3.61 \pm 0.084$ & $6.24 \pm 0.244$ \\
\hline$\overline{\mathrm{CL}_{\text {tot }}}$ & L/hr/kg & $137.63 \pm 2.34$ & - \\
\hline$\overline{\mathrm{K}_{\mathrm{ab}}}$ & $\overline{h^{-1}}$ & - & $0.561 \pm 0.051$ \\
\hline $\begin{array}{c}\mathrm{t}_{0.5(\mathrm{ab})} \\
\end{array}$ & $\mathrm{h}$ & - & $1.27 \pm 0.114$ \\
\hline $\mathrm{T}_{\max }$ & $\mathrm{h}$ & - & $2.42 \pm 0.039$ \\
\hline$\overline{\mathrm{C}_{\max }}$ & $\mu \mathrm{g} / \mathrm{ml}$ & - & $19.54 \pm 0.366$ \\
\hline $\mathrm{K}_{\mathrm{el}}$ & $\overline{h^{-1}}$ & - & $0.19 \pm 0.01$ \\
\hline MAT & $\bar{h}$ & - & $2.63 \pm 0.16$ \\
\hline
\end{tabular}


A, B and C Zero-time serum drug concentration intercepts of biphasic intravenous disposition curve. The coefficient $B$ is based on the terminal exponential phase $(\mu \mathrm{g} / \mathrm{ml}) ; \alpha$ \& $\beta$, Hybrid rate constant of biphasic intravenous disposition curve values of $\alpha$ and $\beta$ are related to the slopes of distribution and elimination phase respectively, of biexponential drug disposition curve $\left(\mathrm{h}^{-1}\right)$; AUC, Total area under the plasma drug concentration versus time curve from $\mathrm{t}=0$ to $\mathrm{t}=\alpha$ after administration of a single dose; $\mathrm{C}$ max, Maximum serum concentration of drug in blood after extra vascular administration $(\mu \mathrm{g} / \mathrm{ml}) ; \mathrm{Cl}_{\text {tot }}$, The total clearance of a drug, which represents the sum of all clearance processes in the body $(\mathrm{ml} / \mathrm{kg}$ /min); $\mathrm{K}_{12}$, First - order transfer rate constant for drug distribution from central to peripheral compartment $\left(\mathrm{h}^{-1}\right) ; \mathrm{K}_{21}$, First order transfer rate constant for drug distribution from peripheral to central compartment $\left(\mathrm{h}^{-1}\right) ; \mathrm{t}_{0.5(\alpha)}$, Distribution half - life (h); $\mathrm{t}_{0.5(\beta)}$, Elimination half - life ; $t_{\max }$, The time at which the maximum concentration of drug was reached after extravascular administration (h); $\mathrm{V}_{\mathrm{dss}}$, The apparent volume of distribution which was calculated by Steady - state method $(\mathrm{ml} / \mathrm{kg})$. 
Table 2: Pharmacokinetic parameters of cefotxime in healthy $(\mathrm{H})$ and experimentally Staphylococcus aureus infected chickens (I) during repeated intramuscular injection of $25 \mathrm{mg} / \mathrm{kg}$ b.wt. twice daily for 5 consecutive days $(\mathrm{n}=4)$.

\begin{tabular}{|c|c|c|c|c|c|c|c|c|c|c|c|}
\hline \multirow{2}{*}{$\begin{array}{r}\text { Parame } \\
\text { ter }\end{array}$} & \multirow[t]{2}{*}{ Unit } & \multicolumn{2}{|c|}{$1^{\text {st }}$ dose } & \multicolumn{2}{|c|}{$3^{\text {rd }}$ dose } & \multicolumn{2}{|c|}{$5^{\text {th }}$ dose } & \multicolumn{2}{|c|}{$7^{\text {th }}$ dose } & \multicolumn{2}{|c|}{$9^{\text {th }}$ dose } \\
\hline & & $\mathrm{H}$ & I & $\mathrm{H}$ & I & $\mathrm{H}$ & I & $\mathrm{H}$ & I & $\mathrm{H}$ & I \\
\hline $\mathrm{K}_{\mathrm{ab}}$ & $h^{-1}$ & $\begin{array}{l}0.590 \\
\pm 0.036\end{array}$ & $\begin{array}{l}0.431 \\
\pm 0.03 *\end{array}$ & $\begin{array}{l}0.886 \\
\pm 0.046\end{array}$ & $\begin{array}{l}0.77 \\
\pm 0.035\end{array}$ & $\begin{array}{l}1.01 \\
\pm 0.065\end{array}$ & $\begin{array}{l}0.963 \\
\pm 0.065\end{array}$ & $\begin{array}{l}0.93 \\
\pm 0.007\end{array}$ & $\begin{array}{l}0.988 \\
\pm 0.043\end{array}$ & $\begin{array}{l}1.18 \\
\pm 0.036\end{array}$ & $\begin{array}{l}1.68 \\
\pm 0.049 * * *\end{array}$ \\
\hline $\mathrm{t}_{0.5(\mathrm{ab})}$ & $\mathrm{H}$ & $\begin{array}{l}1.19 \\
\pm 0.075\end{array}$ & $\begin{array}{l}1.63 \\
\pm 0.101^{*}\end{array}$ & $\begin{array}{l}0.789 \\
\pm 0.039\end{array}$ & $\begin{array}{l}0.905 \\
\pm 0.038^{*}\end{array}$ & $\begin{array}{l}0.694 \\
\pm 0.044\end{array}$ & $\begin{array}{l}0.729 \\
\pm 0.044\end{array}$ & $\begin{array}{l}0.746 \\
\pm 0.006\end{array}$ & $\begin{array}{l}0.706 \\
\pm 0.031\end{array}$ & $\begin{array}{l}0.587 \\
\pm 0.018\end{array}$ & $\begin{array}{l}0.414 \\
\pm 0.012 * * *\end{array}$ \\
\hline $\mathrm{T}_{\max }$ & $\mathrm{H}$ & $\begin{array}{l}2.36 \\
\pm 0.021\end{array}$ & $\begin{array}{l}2.45 \\
\pm 0.022 *\end{array}$ & $\begin{array}{l}2.23 \\
\pm 0.043\end{array}$ & $\begin{array}{l}2.30 \\
\pm 0.039\end{array}$ & $\begin{array}{l}2.48 \\
\pm 0.062\end{array}$ & $\begin{array}{l}2.50 \\
\pm 0.084\end{array}$ & $\begin{array}{l}2.46 \\
\pm 0.007\end{array}$ & $\begin{array}{l}2.33 \\
\pm 0.039 *\end{array}$ & $\begin{array}{l}2.27 \\
\pm 0.033\end{array}$ & $\begin{array}{l}1.85 \\
\pm 0.025^{* * *}\end{array}$ \\
\hline $\mathrm{C}_{\max }$ & $\mu \mathrm{g} / \mathrm{ml}$ & $\begin{array}{l}19.05 \\
\pm 0.107\end{array}$ & $\begin{array}{l}17.23 \\
\pm 0.312 * *\end{array}$ & $\begin{array}{l}20.96 \\
\pm 0.273\end{array}$ & $\begin{array}{l}18.63 \\
\pm 0.108 * * *\end{array}$ & $\begin{array}{l}30.3 \\
\pm 0.290\end{array}$ & $\begin{array}{l}27.34 \\
\pm 0.687 * *\end{array}$ & $\begin{array}{l}45.53 \\
\pm 0.035\end{array}$ & $\begin{array}{l}38.85 \\
\pm 0.543 * * *\end{array}$ & $\begin{array}{l}51.03 \\
\pm 0.32\end{array}$ & $\begin{array}{l}42.38 \\
\pm 0.183 * * *\end{array}$ \\
\hline $\mathrm{K}_{\mathrm{el}}$ & $h^{-1}$ & $\begin{array}{l}0.20 \\
\pm 0.005\end{array}$ & $\begin{array}{l}0.217 \\
\pm 0.016\end{array}$ & $\begin{array}{l}0.142 \\
\pm 0.004\end{array}$ & $\begin{array}{l}0.161 \\
\pm 0.002 * *\end{array}$ & $\begin{array}{l}0.10 \\
\pm 0.005\end{array}$ & $\begin{array}{l}0.104 \\
\pm 0.003\end{array}$ & $\begin{array}{l}0.09 \\
\pm 0.008\end{array}$ & $\begin{array}{l}0.104 \\
\pm 0.006\end{array}$ & $\begin{array}{l}0.071 \\
\pm 0.006\end{array}$ & $\begin{array}{l}0.060 \\
\pm 0.010\end{array}$ \\
\hline $\mathrm{t}_{0.5(\beta)}$ & $\mathrm{H}$ & $\begin{array}{l}3.48 \\
\pm 0.093\end{array}$ & $\begin{array}{l}3.25 \\
\pm 0.243\end{array}$ & $\begin{array}{l}4.9 \\
\pm 0.139\end{array}$ & $\begin{array}{l}4.32 \\
\pm 0.062 * *\end{array}$ & $\begin{array}{l}7.00 \\
\pm 0.379\end{array}$ & $\begin{array}{l}6.69 \\
\pm 0.213\end{array}$ & $\begin{array}{l}7.88 \\
\pm 0.748\end{array}$ & $\begin{array}{l}6.72 \\
\pm 0.407 * *\end{array}$ & $\begin{array}{l}9.96 \\
\pm 0.748\end{array}$ & $\begin{array}{l}12.30 \\
\pm 1.54 * * *\end{array}$ \\
\hline AUC & $\mathrm{hr} / \mu \mathrm{g} / \mathrm{mL}$ & $\begin{array}{l}139.26 \\
\pm 0.508\end{array}$ & $\begin{array}{l}123.01 \\
\pm 2.45 * * *\end{array}$ & $\begin{array}{l}186.21 \\
\pm 3.71\end{array}$ & $\begin{array}{l}153.7 \\
\pm 2.97 * * *\end{array}$ & $\begin{array}{l}380.16 \\
\pm 10.7\end{array}$ & $\begin{array}{l}328.81 \\
\pm 8.87 * *\end{array}$ & $\begin{array}{l}574.47 \\
\pm 21.94\end{array}$ & $\begin{array}{l}445.88 \\
\pm 7.45^{* *}\end{array}$ & $\begin{array}{l}766.65 \\
\pm 27.61\end{array}$ & $\begin{array}{l}728.32 \\
\pm 48.65\end{array}$ \\
\hline AUMC & $\mathrm{hr} / \mathrm{hr} / \mu \mathrm{g} / \mathrm{ml}$ & $\begin{array}{l}819.37 \\
\pm 12.14\end{array}$ & $\begin{array}{l}693.16 \\
\pm 42.72 *\end{array}$ & $\begin{array}{l}1428.0 \\
\pm 43.56\end{array}$ & $\begin{array}{l}1070.7 \\
\pm 34.18^{* * *}\end{array}$ & $\begin{array}{l}4162.4 \\
\pm 306.4\end{array}$ & $\begin{array}{l}3452.36 \\
\pm 149.88\end{array}$ & $\begin{array}{l}6873.67 \\
\pm 733.58\end{array}$ & $\begin{array}{l}4651.23 \\
\pm 257.17 * *\end{array}$ & $\begin{array}{r}11248.45 \\
\pm 1036.21\end{array}$ & $\begin{array}{l}13197.7 \\
\pm 2059.15\end{array}$ \\
\hline MRT & $\mathrm{H}$ & $\begin{array}{l}5.88 \\
\pm 0.067\end{array}$ & $\begin{array}{l}5.62 \\
\pm 0.243\end{array}$ & $\begin{array}{l}7.72 \\
\pm 0.111\end{array}$ & $\begin{array}{l}6.96 \\
\pm 0.09 * *\end{array}$ & $\begin{array}{l}10.91 \\
\pm 0.502\end{array}$ & $\begin{array}{l}10.49 \\
\pm 0.249\end{array}$ & $\begin{array}{l}11.87 \\
\pm 0.816\end{array}$ & $\begin{array}{l}10.41 \\
\pm 0.412\end{array}$ & $\begin{array}{l}14.58 \\
\pm 0.854\end{array}$ & $\begin{array}{l}17.75 \\
\pm 1.85\end{array}$ \\
\hline
\end{tabular}

\footnotetext{
$* \mathrm{P}<0.05, * * \mathrm{P}<0.01, * * * \mathrm{P}<0.001$.
} 
Table 3: Tissue concentrations of cefotaxime $(\mu \mathrm{g} / \mathrm{ml})$ in healthy $(\mathrm{H})$ and experimentally Staphylococcus aureus infected chickens (I) during repeated intramuscular injection of $25 \mathrm{mg} / \mathrm{kg}$ b.wt. twice daily for 5 consecutive days $(\mathrm{n}=3)$.

$$
\text { After } 24 \mathrm{~h}
$$

Tissue

$\mathrm{H}$

I

$23.17 \pm 0.614 \quad 15.51 \pm 0.31 * * *$

$17.52 \pm 0.311$

$11.56 \pm 0.34 * * *$

$10.5 \pm 0.324$

$7.72 \pm 0.16^{* * *}$

$5.66 \pm 0.592$

$2.01 \pm \quad 2.05$

$0.312 \pm 0.087$

Kidney
Lung
Heart
Brain
Skin \&
Fat
Breast
muscle
Thigh
muscle
$16.69 \pm 0.405 \quad 10.94 \pm 0.04 * * * \quad 7.43 \pm 0.233$

$14.04 \pm 0.52 \quad 7.92 \pm 0.395 * * *$

$5.57 \pm 0.367$

$5.34 \pm 0.347 * *$

$2.71 \pm 0.147 * * *$

$4.64 \pm 0.319$

$2.36 \pm 0.427$

$1.3 \pm 0.29 * * *$

$1.14 \pm 0.063$

**

$-$

- $\quad-$

$* \mathrm{P}<0.05$, 


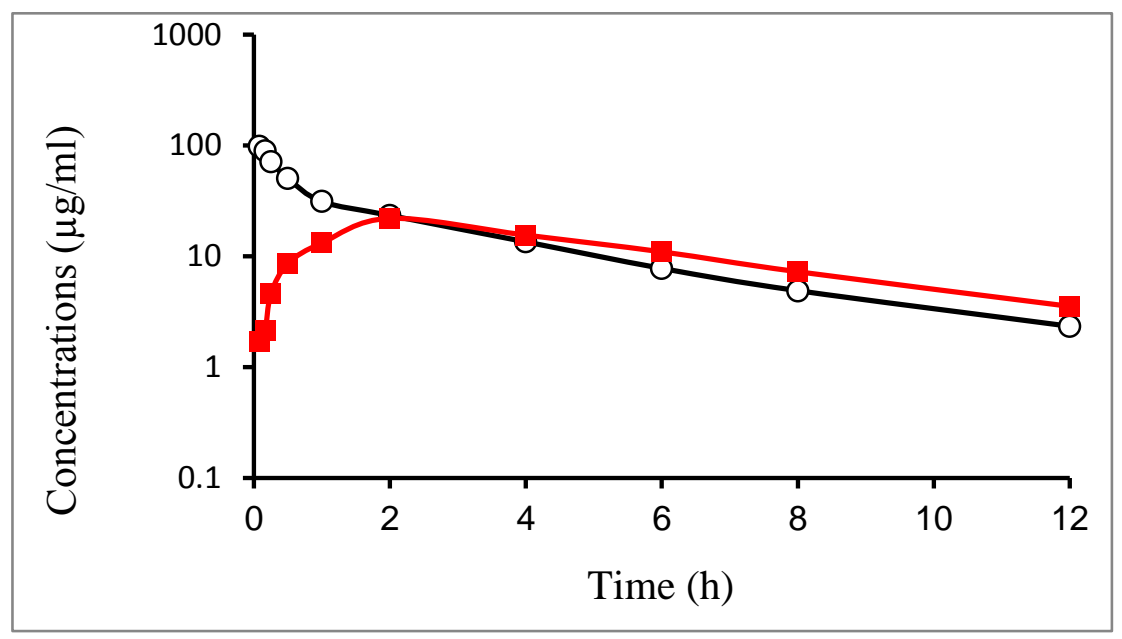

$\mathrm{S}$

Figure (1): Arithmic plot of serum of cefotaxime concentration in healthy chickens following a single intramuscular injection of $25 \mathrm{mg} / \mathrm{kg}$.b.wt. (口- ${ }^{-}$) in chickens previously given the same dose by intravenous injection $(-)(n=6)$.

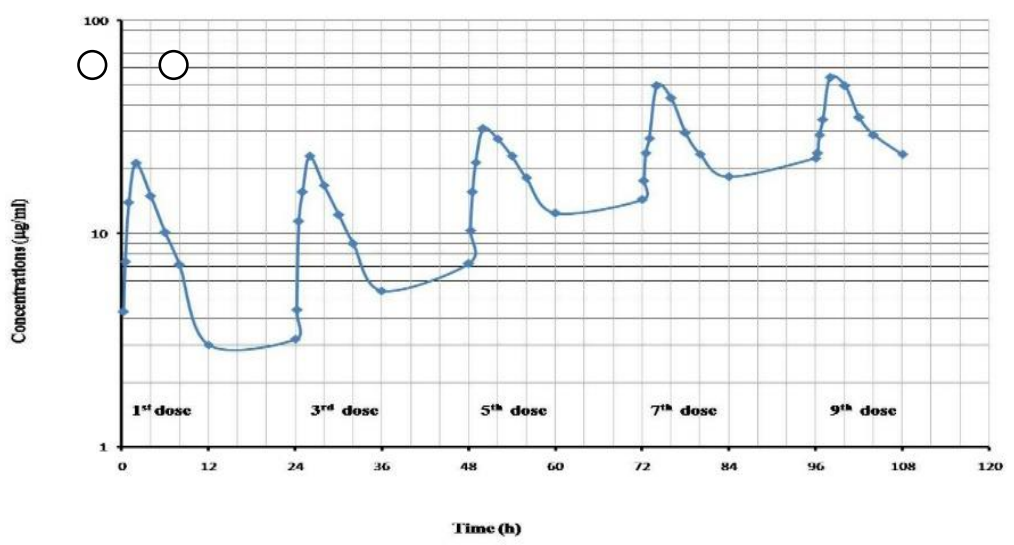

Figure (2): Semi logarithmic graph depicting the time course of cefotaxime following repeated intramuscular injection of $25 \mathrm{mg} / \mathrm{kg}$ b.wt. twice daily for 5 consecutive days in serum of healthy chickens $(n=4)$.

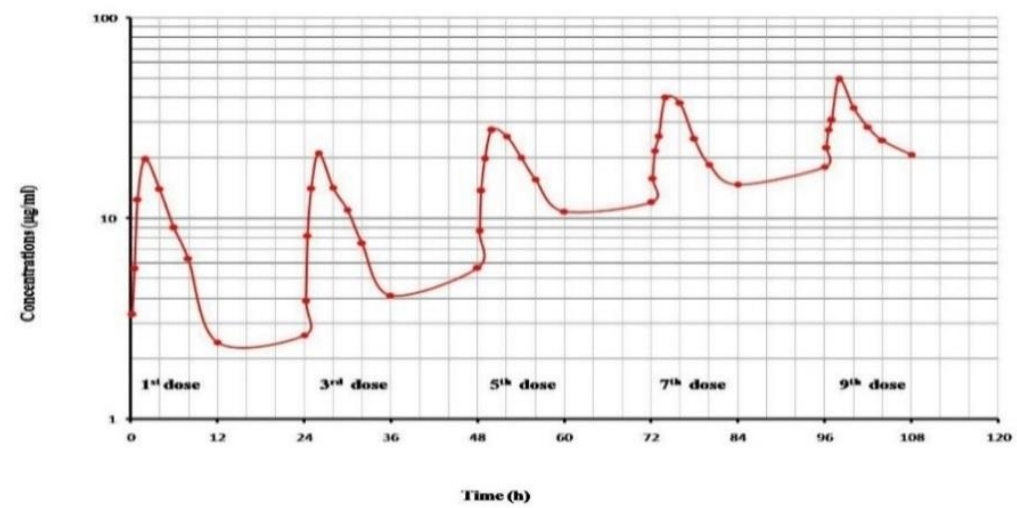

Figure (3): Semi logarithmic graph depicting the time course of cefotaxime following repeated intramuscular injection of $25 \mathrm{mg} / \mathrm{kg}$ b.wt. twice daily for 5 consecutive days in serum of experimentally Staphylococcus aureus infected chickens $(n=4)$. 


\section{DISCUSSION:}

In the present investigation, I.V. injection of $25 \mathrm{mg}$ of cefotaxime $/ \mathrm{kg} \mathrm{b}$. wt. in normal chickens showed that the disposition best fitted two compartments open model. The obtained result was consistent with those reported for cefotaxime in goats (El-Sayed et al.,2015b), in muscovy ducks (Aboubaker, 2016) and in broiler chickens (Hesham and Elbakery, 2017).

The $\mathrm{V}_{\mathrm{dss}}$ is a clearance - independent volume of distribution that is used to calculate the drug amount in the body under equilibrium conditions. The $\mathrm{V}_{\mathrm{dss}}$ for cefotaxime was $496.90 \pm 15.47 \mathrm{ml} / \mathrm{kg}$ suggesting higher penetration through biological membranes and tissue distribution after intravenous administration in broiler chickens. The obtained value was shorter than the data reported after intravenous administration of cefotaxime in buffalo calves $(1.48 \mathrm{~L} / \mathrm{kg})$ and in Muscovy ducks $(0.51 \mathrm{~L} / \mathrm{kg}$ ) (Sharma et al., 2005; Aboubakr, 2016), respectively. On the other hand, volume of distribution was higher than these recorded for cefotaxime in broiler chickens $(0.45 \mathrm{~L} / \mathrm{kg}$; Hesham and El-bakery, 2017).

In comparison with other cephalosporins, this $\mathrm{V}_{\mathrm{dss}}$ value agreed with the data reported after intravenous injection of cefpime in calves $(0.43 \mathrm{~L} / \mathrm{kg}$; Urvesh et al., 2006), cefquinome in ducks $(0.41 \mathrm{~L} / \mathrm{kg}$; Yaun et al., 2011), cefquinome in chickens (0.49 $\mathrm{L} / \mathrm{kg}$; Xie et al., 2013), cefepime in goats $(0.44 \quad \mathrm{~L} / \mathrm{kg} ; \quad$ El-Heweity, 2014) and cefoperazone in goats $(0.44 \mathrm{~L} / \mathrm{kg}$; Taha et al., 2015).

On the other hand, this $\mathrm{V}_{\mathrm{dss}}$ value was higher than those recorded for ceftriaxone in dogs (0.217 L/kg; Rebuelto et al., 2002); cefepime in calves and ewes $(0.21$ and 0.32
$\mathrm{L} / \mathrm{kg}$; Ismail, 2005a; Ismail, 2005c, respectively; ceftiofur in calves $(0.134 \mathrm{~L} / \mathrm{kg}$; El-Gendy et al., 2007); ceftiofur in camel (0.13 L/kg; Goudah, 2007); ceftiofur in cow (0.178 L/kg; Tohamy, 2008); ceftriaxone in buffalo (0.36 L/kg; Gohil et al., 2009 ); cefpirome in cow calves $(0.33 \mathrm{~L} / \mathrm{kg}$; Patel et al., 2013); ceftiofur in chickens (198.60 ml/kg; El-Sayed et al., 2015a); cefquinome in chickens (389.23 ml/kg; El-Sayed et al., 2015 c); ceftriaxone in goats $(0.355 \mathrm{~L} / \mathrm{Kg}$; ElSayed et al., 2016a) and cephradine in chickens (328.94 ml/kg; El-Sayed et al., 2016b).

On the other hand, volume of distribution $\left(\mathrm{V}_{\mathrm{dss}}\right)$ was shorter than that recorded in cefepime in rabbits $(1.168 \mathrm{~L} / \mathrm{kg}$; Abd El-Aty et al., 2007); ceftriaxone in domestic cats $(0.57 \mathrm{~L} / \mathrm{kg}$; Albarellos et al., 2007); cefepime in sheep $(0.42 \mathrm{~L} / \mathrm{kg}$; Patel et al., 2010); cefoperazone in sheep $(0.51 \mathrm{~L} / \mathrm{kg}$; Soni et al., 2012) and cefquinome in goats (0.51 L/kg; Dumka et al., 2013).

Cefotaxime was transferred from central to peripheral compartment at a slower rate $\left(\mathrm{K}_{12}=1.51 \mathrm{~h}^{-1}\right)$ than its passage from peripheral compartment to central compartment $\left(\mathrm{K}_{21}=1.02 \mathrm{~h}^{-1}\right)$. These values were nearly similar to that reported for ceftiofur in buffalo calves $\left(\mathrm{K}_{12}=1.557 \mathrm{~h}^{-1}\right)$ and $\left(\mathrm{K}_{21}=2.003 \mathrm{~h}^{-1}\right)$ by El-Gendy et al., (2007) and cefquinome in chickens $\left(\mathrm{K}_{12}=\right.$ $\left.0.713 \mathrm{~h}^{-1}\right)$ and $\left(\mathrm{K}_{21}=1.06 \mathrm{~h}^{-1}\right)$ by El-Sayed $e t$ al., 2015c).

The elimination half-life $\left[\mathrm{t}_{0.5(\beta)}\right]$ of cefotaxime following single intravenous injection of $25 \mathrm{mg} / \mathrm{kg}$ b.wt was equal to 3.11 h. This observation agreed with the data reported after intravenous administration of cephalexin in calves $(3.17 \mathrm{~h}$; Garg et al., 1996); ceftazidime in rabbits $(2.22 \mathrm{~h}$; Abd ElAty et al., 2001), cefepime in calves $(3.7 \mathrm{~h}$; 
Urvesh et al., 2006), cefepime in rabbits (2.935 h; Abd El-Aty et al., 2007), cefoperazone in sheep $(3.8 \mathrm{~h}$; Soni et al., 2012), ceftazidime in dromedary camels (2.85 h; Goudah et al., 2013) and cefepirome in cow calves (2.41 h; Patel et al., 2013) and cephradine in chickens $(2.79 \mathrm{~h}$; El-Sayed et al., 2016b).

On contrast, the obtained value was longer than those recorded in cefuroxime in goats (1.48 h; Abo El-Sooud et al., 2000), cefepime in ewes (1.76 h; Ismail, 2005c), ceftriaxone in cats $(1.73 \mathrm{~h}$; Albarellos et al., 2007), ceftiofur in buffalos $(1.607 \mathrm{~h}$; ElGendy et al., 2007), cefquinome in piglets (1.85 h; Li et al., 2008), ceftriaxone in buffalo (1.27 h; Gohil et al., 2009), ceftriaxone in cows (1.02 h; Kumar et al., 2010), cefquinome in ducks and chickens $(1.57,1.29 \mathrm{~h}$; Yuan et al., 2011 and Xie et al., 2013, respectively), ceftriaxone in goats $(1.82 \pm 0.13 \mathrm{~h})$ (Prashant et al.,2014); cefquinome in chickens $(0.712 \pm 0.05$ h )( El-Sayed et al.,2015c) and cefoperazone in goats $(1.97 \pm 0.14 \mathrm{~h})($ Taha et al.,2015).

On the other hand, it was shorter than those showed in cephradine in goats $(4.00 \mathrm{~h}$; El-Sayed et al., 1994 ); ceftriaxone in calves (4.39 $\pm 0.63 \mathrm{~h}$; Johal et al.,1999) ; ceftiofur in fresian calves ( $5.047 \mathrm{~h}$;El-Gendyet al., 2007) ; cefquinome in goats $(5.76 \mathrm{~h}$; Dumkaet al., 2013); cefepimein goats $(3.34 \pm 0.12 \mathrm{~h}$; ElHewaity ,2014); ceftiofur in chickens ( $5.47 \mathrm{~h}$ ; El-Sayed et al., 2015a) and ceftriaxone in goats (5.19 h ; El-Sayed et al., 2016a).

The rate of total body clearance $\left[\mathrm{CL}_{\mathrm{tot}}\right]$ of cefotaxime following intravenous injection was $0.138 \pm 2.34 \mathrm{~L} / \mathrm{kg} / \mathrm{hr}$. The clearance values of cefotaxime in muscovy ducks and broiler chickens were $(0.22 \pm 0.008$ and $0.08 \pm$ $0.01 \mathrm{~L} / \mathrm{Kg} / \mathrm{hr}$ ) (Aboubaker, 2016 ; Hesham and El-bakery,2017, respectively ).
Following a single intramuscular administration of $25 \mathrm{mg} / \mathrm{kg}$ b.wt. the drug reached its maximum concentration $(22.14 \pm$ $0.418 \mu \mathrm{g} / \mathrm{ml}$ ) at 2 hours and could be detected in serum in therapeutic level $(3.54 \pm 0.210$ $\mu \mathrm{g} / \mathrm{ml}$ ) for 12 hours. On the bases of cefotaxime concentration for avian pathogenic microorganisms, it was suggested that intramuscular administration of $25 \mathrm{mg} / \mathrm{kg}$ b.wt. with 12 hours intervals should be adequate for control of avian bacterial diseases. These concentrations exceeded the minimum inhibitory concentrations $4 \mu \mathrm{g} / \mathrm{ml}$ for staphylococcus species (Craig, 1995).

Maximal serum concentration $\left(\mathrm{C}_{\max }\right)$ $(19.54 \pm 0.366 \mu \mathrm{g} / \mathrm{ml})$ achieved at $\left(t_{\max }\right)$ (2.42 \pm 0.039 hours). These values were higher than to those recorded for cefotaxime in Muscovy ducks $\left(\mathrm{C}_{\max }\right)(14.72 \pm 0.29 \mu \mathrm{g} / \mathrm{ml})$ and $\left(\mathrm{t}_{\max }\right)(2.30 \pm 0.02$ hours) (Aboubaker, 2016) and lower than to those recorded for cefotaxime in chickens $\left(\mathrm{C}_{\max }\right)(25.02 \pm 0.01$ $\mu \mathrm{g} / \mathrm{ml})$ and $\left(\mathrm{t}_{\max }\right)(1.08 \pm 0.01 \mathrm{~h})($ Hesham and El-bakery, 2017).

The bioavailability of cefotaxime in normal chickens, which estimated the rate and extent of the dose entered the systemic circulation after oral administration was 81.92 $\pm 2.81 \%$. This percent indicated a good absorption of cefotaxime after intramuscular administration. This value was nearly similar to those recorded for ceftriaxone in goats and calves (85\% and $85.72 \%$ ) (Ismail, 2005b; Albarellos et al., 2007) and cefotaxime in Muscovy ducks and chickens (79.61 $\pm 1.82 \%$ and 85.11 $\pm 1.00 \%$ ) (Aboubaker, 2016; Hesham and El-bakery, 2017).

In this study, results indicated that cefotaxime could be detected in a therapeutic level for 12 hours in serum following repeated intramuscular administrations. These concentrations exceeded the minimum 
inhibitory concentrations (4 $\mu \mathrm{g} / \mathrm{ml})$ for staphylococcus species (Craig, 1995).

The study showed that the blood concentrations of cefotaxime in Staphylococcus aureus infected chickens were significantly lower than those in normal chickens following repeated intramuscular administrations. This phenomenon agreed with the data recorded by (Soliman, 2000), who found that enrofloxacin concentrations in plasma of infected birds were lower than those of healthy ones. El- Sayed et al. (1994) proved that, the serum concentrations of cephradine following intramuscular administration on 10 $\mathrm{mg} / \mathrm{kg}$. b.wt. twice daily for five consecutive days, peaked 2 hours after each intramuscular dose with lower significant values recorded in Escherichia coli infected goats than in normal goats.

Following repeated intramuscular injection of $25 \mathrm{mg}$ cefotaxime/kg b.wt twice daily in normal and Staphylococcus aureus infected chickens for five consecutive days, the drug could not be detected by microbiological assay in all tested tissues except in liver (120 h), kidneys (96 h) and lung $(72 \mathrm{~h})$ of chickens post last administrations. Drug concentrations in liver, kidney and lung were (23.17 \pm 0.614$),(16.69 \pm$ $0.405)$ and $(14.04 \pm 0.52) \mu \mathrm{g} / \mathrm{g}$ respectively 24 hours after the stoppage of drug medication in normal chickens. Drug could not be detected in all tested tissues except in liver (96 h), kidney $(72 \mathrm{~h})$ and lung (48 h). Drug concentrations in liver, kidney and lung were $(15.51 \pm 0.31),(10.94 \pm 0.04)$ and $(7.92 \pm$ $0.395) \mu \mathrm{g} / \mathrm{g}$ respectively 24 hours after the stoppage of drug medication in Staphylococcus aureus infected chickens. In particular the high clearance of cefotaxime indicates the reduced possibility of finding residues of antimicrobial in broiler chickens a few days after treatment and necessity of shorter withdrawal time for this antimicrobial i.e. five days.

\section{CONCLUSION:}

The intramuscular bioavailability of cefotaxime is excellent, so it is recommended to be used against Staphylococcus aureus infection. Repeated intramuscular injection of cefotaxime $(25 \mathrm{mg} / \mathrm{kg} \mathrm{b}$.wt.) twice daily for five consecutive days would provide an effective concentration against Staphylococcus aureus in broiler chickens. Treated chickens must not be slaughtered before six days from last dose of repeated injection of cefotaxime to withdraw the drug residues from all tissues of treated chickens.

\section{REFERENCES:}

Abd El-Aty, A.M.; Goudah, A. and Abo ElSooud K. (2001). Pharmacokinetics, intramuscular bioavailability and tissue residue profiles of ceftazidime in a rabbit model.Dtsch. Tier. Wochen., 108(4): 168-171.

Abd El-Aty, A.M.; Goudah, A; Mouneir, S.M.; Sunwoo, Y.E.; Jang, J.H.; Shin, J.G.; Shim, J.H. and Shimoda M. (2007). Acute - phase response alters the disposition kinetics of cefepime following intravenous administration to rabbits. Vet. Res. Commun., 31(1): 67-75.

Abo El-Sooud, K.; El-Banna, H.A.; Hanafy, M.S. and Goudah A. (2000). Pharmacokinetics and intramuscular bioavailability of cefuroxime sodium in goats. Res. Vet. Sci., 69 (3): 219224.

Aboubaker, M. (2016). Bioavailability and pharmacokinetics of cefotaxime in Muscovy ducks. Int. J. Pharmacol. Toxicol., 4(1): 93-95. 
Albarellos, G.A.; Kriel, V.E. and Landoni M.F. (2007). Pharmacokinetics of ceftriaxone after intravenous, intramuscular and subcutaneous administration to domestic cats. J. Vet. Pharmacol. Therap., 30(4): 345352.

Arret, B.; Johnson, D.P. and Kirshbaum, A. (1971). Outline of details for microbiological assay of antibiotics: Second revision. J. Pharm. Sci, 60(11): 1689-1694.

Atef, M.; Ramadan, A.; Afifi, N.A. and Youssef S.A.H. (1990). Pharmacokinetic profile of cefotaxime in goats: Res. Vet. Sci. 49(1): 34-38.

Baggot, J.D. (1978 a). Some aspects of clinical pharmacokinetics in veterinary medicine I. J. Vet. Pharmacol. Therap., I:5-18.

Baggot, J.D. (1978 b). Some aspects of clinical pharmacokinetics in veterinary medicine II. J. Vet. Pharmacol. Therap., II: 111-118.

Craig, W.A. (1995). Interrelationship between pharmacokinetics and pharmacodynamics in determining dosage regimens for broad spectrum cephalosporins. Diag. Microb. And Infec. Dis., 22(1): 89-96.

Dumka, V.K.; Dinakaran, V.;Ranjan, B. and Rampal S. (2013). Comparative pharmacokinetics of cefquinome following intravenous and intramuscular administration in goats. Small Rum. Res., 113(1): 237277.

Dutta, P.B.; Debnath, S.C.; Mandal, T.K. and Chakraborty A.K. (2004). Modification of pharmacokinetics of cefotaxime in uranyl nitrate-induced renal damage in black bengal goats. J. Vet. Sci., 5(1):1-3.

El - Gendy, A.A.M.; Tohamy, M.A. and Ismail M. (2007). Comparative pharmacokinetic and renal clearance study of ceftiofur in cross breed Freisian and buffalo calves. BeniSuef Vet. Med. J., 17(1): 69-77.

El - Hewaity, M. (2014). Influence of Flunixin on the disposition kinetics of cefepime in goats. Advan. In. Pharm. Sci., Doi:471517: 1-5.

El -Sayed, M.G.; Atef, M. and El-Komy A.A. (1994). Disposition kinetics of cephradine in normal and Escherichia coli infected goats. Dtsch. Tier. Wochen.,101 (2): 56-60.

El -Sayed, M.G.A.; El-Komy, A.A.A.; El barawy, A.M. and Ibrahim, Dalia, M.A. (2015a). Pharmacokinetics and tissue residues of ceftiofur in normal and Escherichia coli infected chickens. J. Phys. Pharm. Adv.,5(3): 574-582.

El -Sayed, M.G.A.; El-Komy, A.A.A. and salah, Eman. (2015 b). Pharmacokinetics of cefotaxime in goats following multiple dosing. Int. J. Biopharm. Sci., 6(3): 115-120.

El- Sayed, M. G. A.; El-Komy, A. A.A.; Elham, A.M. and El-Mahdy A.M. (2015c). Pharmacokinetics and tissue residues of cefquinome in normal and salmonella entretidis infected chickens. World J. Pharm. Pharm. Sci., 4(10): 1974-1987.

El -Sayed, M.G.A.; El-Komy, A.A.A. and El -Sayed, Faten, I. (2016a). Pharmacokinetics of ceftriaxone in normal and Salmonella Typhimurium 
infected goats. World J. Pharm. Pharm. Sci., 5(2): 1433-1458.

El -Sayed, M.G.A.; Aboubakr, M. and Rabea, Samar. (2016b). Pharmacokinetics and tissue residues of cephradine in healthy and experimentally Salmonella Enteritidis infected chickens. World J. Of Pharm. And Pharmaceu. Sci., 5(6): 61-74.

Garg, S.K.; Chaudhary, R.K. and Srivastava A.K. (1996). Pharmacokinetics of cephalexin in calves after intravenous and subcutaneous administration. Acta Vet. Hung., 44(2): 195-201.

Gohil, P. V.; Patel, U. D.; Bhavsar, S. K. and Thaker A. M. (2009). Pharmacokinetics of ceftriaxone in buffalo calves (Bubalus bubalis) following intravenous and intramuscular administration. Iran. J. Vet. Res., Shiraz Uni.,10 (1) : 33-37.

Goudah, A. (2007). Pharmacokinetics of ceftiofur after single intravenous and intravenous and intramuscular administration in camels (Camelus dromedarius). J. Vet. Pharmacol. and Therap., 4: 371-374.

Goudah A.M.; Hasabelnaby S.M. (2013). Pharmacokinetics and distribution of ceftazidime to milk after intravenous and intramuscular administration to lactating female dromedary camels (Camelus dromedaries). J. Am. Vet. Med. Assoc., 243(3): 424-429.

Gu, C.Q.; Hu X.Y.; Xie, C.Q.; Zhang, W.P.; Wang, D.H.; Zhou, Q. and Cheng, G.F. (2013). Observation on arthritis in broiler breeder chickens experimentally infected with staphylococcus aureus. Pak. Vet. J.,
33 (2): 195-199.

Guerrini, V.H.; English P.B.; Filipich L.J.; Schneider J. and Bourne D.W.A. (1983). Pharmacokinetics of cefotaxime in sheep. Am. J. Of. Vet. Res., 44 (8): 1488-1491.

Guerrini V.H.; English P.B.; Filipich L.J.; Schneider J. and Bourne D.W. (1986). Pharmacokinetics of cefotaxime in dog. Vet. Rec., 119 (4): 81-83.

Hesham S.T. and El-bakery, Z.M.A. (2017). Pharmacokinetics, bioavailability and tissue residues of cefotaxime following intramuscular administrations in broiler chickens. An. He. Res. J., 5 (1): 107-115.

Ismail, M.M. (2005a). Disposition kinetics, bioavailability and renal clearance of cefepime in calves. Vet. Res. Commun., 29 (1): 69-79.

Ismail, M.M. (2005b). Pharmacokinetics, urinary and mammary excretion of ceftriaxone in lactating goats. J. Vet. Med. A., 52(7): 354-358.

Ismail, M.M. (2005c). Pharmacokinetics of cefepime administered by intravenous and intramuscular routes to ewes. J. Vet. Pharmacol. Therap., 28 (6): 499-503.

Johal; Bindu and Srivastava A. K. (1999). Disposition kinetics and dosage regimen of ceftriaxone in crossbred calves. Acta Vet. Hung., 47(2) :243248.

Kumar, S.; Srivastava, A.K.; Dumka, V.K.; Kumar, N. and Raina R.K. (2010). Plasma pharmacokinetics and milk levels of ceftriaxone following single intravenous administration in healthy and endometriotic cows. Vet. Res. 
Commun., 34(6): 503-510.

Li, X.B.; Wu, W.X.; Su, D.; Wang, Z.J.; Jiang, H.Y. and Shen J.Z. (2008). Pharmacokinetics and bioavailability of cefquinome in healthy piglet. $\mathrm{J}$. Vet. Pharmacol. Therap., 31(6): 523527.

Marshall, W.F. and Blair J.E. (1999). The cephalosporins. M. Clin. Proc., 74(2): 187-195.

McElory, D.; Ravis, W. and Clark C.H. (1986). Pharmacokinetic of cefotaxime in domestic cats, Am. J. Vet. Res., 47 (1): 86-88.

Neu, H.C. (1982). The new beta-lactamase stable cephalosporins. Ann. Intern. Med., 97: 408-419.

Neu, H.C.; Aswapokee, N.; Aswapokee, P. and Fu K.P. (1979). Thr 756, a new cephalosporin active against grampositive and gram-negative aerobic and anaerobic bacteria. Antimicrob. Ag. Chemother., 15: 273-281.

Olofsson, S.K. (2006). Relation between drug exposure and selection of antibiotic resistant bacteria. Acta. Univ. Ups. Dig. Comp. Summ. Of Upp. Dis. Diva:7197: 72-77.

Orsini, J. A.; Moate, P. J.; Engiles, J.; Norman, T.; Poppenga, R.; Benson, C. E.; and Boston R. C. (2004). Cefotaxime kinetics in plasma and synovial fluid following intravenous administration in horses. J. Vet. Pharmacol. Therap., 27: 293-298.

Patel, P.N.; Patel U.D.; Bhavsar, Sh. K. and Thaker A.M. (2010). Pharmacokinetics of Cefepime following intravenous and intramuscular administration in sheep. Iran. J. Pharmcol.
Therap.,9(1): 7-10.

Patel, A.J.; Bhavsar, S.K.; Patel, H.B.; Patel, N.N.; Patel, S.D.; Dewda, S.; Patel, J. H. and Thaker A.M. (2012a). Effect of ketoprofen coadministration or febrile state on pharmacokinetics of cefepime in goats. Asian J. Anim Vet. Adv., 7(1): 46-53.

Patel, R.B.; Bhavsar, S.K.; Solanki, P. F.; Patel, J.H.; Varia, R.D.; ModiFalguni, D. and Patel M.D. (2013). Pharmacokinetics of cefpirome following intravenous and intramuscular administration in cow calves.Sci. Intern., 1(11):371-374.

Prashant, M.N.; Karmakar, U. K.; Suman, S.; Mishra, A. K.; Datta, B. K.; Chakraborty, A. K.; Mandal, T. K. and Sar T. K. (2014). Disposition kinetics of ceftriaxone and sulbactam $(1: 1)$ in black bengal goats with experimental mastitis. Asian J. Pharmacol. And Toxicol., 2 (7): 717.

Rebuelto, M.; Albarellos, G.; Ambros, L.; Kreil, V.; Montoya, L.; Bonafine, R.; Otero, P. and Hallu R. (2002). Pharmacokinetics of ceftriaxone administered by intravenous, intramuscular or subcutaneous routes to dogs. J.Vet. Pharmacol. and Therap., 25 (1): 73-76.

Ritchel, W.A. (1973). Angew and tebiophomazie, wissenschoftlicheverlaggesellschoft. mbtt, Stuttgart, p.533.

Sharma, S.K.; Srivastava, A. K. and Bal M.S. (1995). Disposition kinetics and dosage regimen of cefotaxime in cross-bred male calves. Vet. Res. 
Bio. Med. Cen., 26(3):168-173.

Sharma, S.K. and Srivastava A. K. (2003). Cefotaxime pharmacokinetics in male buffalo calves following multiple dosing. Vet. Arhiv, 73 (4): 191-197.

Sharma, S.K.; Srivastava, A. K. and Deore M.D. (2005). Pharmacokinetics of cefotaxime in hepatic-dysfunctioned buffalo calves. Vet. Arhiv.,75(4): 339-348.

Sharma, S.K. and Srivastava A. K. (2006). Subcutaneous pharmacokinetics and dosage regimen of cefotaxime in buffalo calves (Bubalus bubalis). J. Vet. Sci., 7(2):119-122.

Snedecor, G.W. and Cokran W.G. (1980). Statistical methods, 7th edition. The Iowa State College. Press, Ames, Iowa, USA,39-63.

Soliman, G.A. (2000). Tissue distribution and disposition kinetics of enrofloxacin in healthy and E. coli infected broilers. (DTW) Dtsch. Tier. Wochen., 107(1): 23-27.

Soni, H.H.; Patel, R.J.; Sadariya, K.A.; Devada, S.S.; Bhavsar, S.K. and Thaker A.M. (2012). Single dose pharmacokinetics of cefoperazone following intravenous and intramuscular administration in sheep. Israel J. Vet. Med., 67(4): 220-223.

Taha, A.; Ashraf, E.; Mohamed, E.; Abd El Latif, Amera and Saber E. (2015).
Comparative pharmacokinetics of cefoperazone following intravenous and intramuscular administration in goats. Int. J. Of Vet. Sci. Med., 3(1): 21-25.

Tohamy, M.A. (2008). Pharmacokinetic of ceftiofur sodium administered concomitantly with dipyrone in healthy and feverish cows. J. Egypt. Soc. Pharmacol. Exp. Therap. ,29(2): 539-550.

Tuomanen, E. (1986). Newly made enzymes determine ongoing call wall synthesis and the antibacterial effects of cell wall synthesis inhibitors. J. Bact., 167(2): 535-543.

Urvesh, D. P.; Shailesh, K. B. and Aswin M. T. (2006). Pharmacokinetics and dosage regimen of cefepime following single dose intravenous administration in calves. Iran. J. Pharmacol. Therap.,5(2): 127-130

Waxman, D.J. and strominger J.L. (1983). Penicillin-binding proteins and the mechanism of action of beta-lactam antibiotics. Annu. Rev. Biochem., 52: 825-869.

Xie, W.; Zhang, X.; Wang, T. and Du, S. (2013). Pharmacokinetic analysis of cefquinome in healthy chickens $\mathrm{Br}$. Poult. Sci., 54(1): 81-86.

Yuan, L. ; Sun, J. ; Wang, R. ; Sun, L. ; Zhu, L. ; Luo, X. ; Fang ,B. and Liu Y. (2011). Pharmacokinetics and bioavailability of cefquinome in healthy ducks. Am. J. Vet. Res.,72 (1): 122-126. 